\title{
Historicism, Coloniality, and Culture in Wartime Japan
}

\section{Hitomi Koyama*}

\begin{abstract}
Historicism has shaped global politics by projecting multiple images of development. Specifically, it has served to legitimise Western forms of hegemony by naturalising the schema of 'First in the West, then in the Rest', thereby damning non-Western Others to the 'waiting room' of history (Chakrabarty 2000). In this light, decolonising international relations must likewise complement efforts to decolonise the stagist views of historicism implicit in civilisational history. However, this focus on stagism neglects the ways in which historicism has also been employed to assert nonWestern agencies in the name of culture, and to legitimise colonialism, as it was in the case of Japan. The case of Japan thus raises the question of whether limiting the critique of historicism to that of being a stagist civilisational discourse is sufficient or not. This article argues that there are not just one but two problems with historicism in international relations: first, that the stagist view of history legitimises the civilising mission; and second, that the romantic turn to culture as a means of resisting Eurocentric history may actually underwrite a colonialist discourse as well. If this is correct, the debate on historicism must not only engage with the concept of civilisation, but also with the concept of culture as a site through which sovereignty is projected.
\end{abstract}

Keywords: Colonialism; Japanese History Problem; Provincialising Europe; Culture; Historicism.

In Japan, as in other postcolonial contexts, the coloniality of history-writing persists. At the end of World War II, the glorification of Japanese imperialism in national history became an object of scrutiny. The historian Saburo Ienaga, for instance, connected state controls over history-writing with an endorsement of Japanese militarism and colonial rule (2003). He later waged a series of battles against the Japanese Ministry of Education, accusing it of censoring history textbooks. Japan's reluctance to address the relationship between history-writing and atonement for its militarist and imperialist past has come to be called 'the history problem' (rekishi mondai). To place the matter in a larger context, International Relations as a discipline tends to adopt a linear view of history that promotes a stagist understanding of historical development (Inayatullah and Blaney 2004). The juxtaposition of a vision of human development with that of unitary humankind constitutes a hierarchical relation between states presumed to be childish and backward and others claiming to be mature, developed and enlightened, thereby legitimising the 'civilising' mission (Mehta 1999). It was in the name of such a 'mission civilisatrice' that Japan legiti-

Australian Catholic University, Sydney-NSW, Australia; Hitomi.koyama@gmail.com. 
mised colonial rule in Korea (Dudden 2005). Both views of history-writing problematise its complicity with colonialism.

Given these histories, efforts to decolonise history have often targeted the ways in which the civilisational, stagist view of history has been appropriated for colonialist ends. In the field of international relations, Dipesh Chakrabarty's call to 'provincialize Europe' has become a rallying point for those who identify with the decolonial and postcolonial approach to the study of global politics. In these literatures, the expansion of European international society, colonial domination, and historicism are strongly associated. Historicism, according to Chakrabarty, 'enabled European domination of the world in the nineteenth century' (2000: 7). The primary cognitive structure identified by Chakrabarty is the notion of 'first in Europe, then elsewhere', which endowed European colonialism with the mission to 'civilise' colonised subjects in its own image (2000: 7; Spivak 1985; Mehta 1999).

Decolonising history, then, is vital. To this end, examining the mutual constitutiveness of history-writing and colonial domination in various geographical settings would further our understanding of how historicism shapes our global imaginary. In this article, I argue that examining modern Japan's use of history in wartime suggests that the civilisational, stagist approach is not the only kind of history-writing we should guard against; we must also be wary of how colonialism and imperialism may be legitimised in the name of culture as resistance against Eurocentrism. Focusing on the Japanese case alone leaves us with a question: If the civilising mission, history-writing, and colonialism go hand in hand, why was Kiyoshi Miki, intellectual architect of the East Asia Cooperative Body and the blueprint for Japan's Greater East Asia Co-Prosperity Sphere, appointed, in 1937, as head of the cultural division of the influential Showa Research Association (SRA), instead of a division of civilisation? Though the notions of 'civilisation' and 'culture' have often been used interchangeably, I argue that they imply disparate conceptions of historical development, as well as different types of 'history problem(s)'.

By beginning with an analysis of the tension inherent in the term 'historicism' itself, I show how it could give rise to two opposing meanings of the term, one civilisational and stagist, the other cultural. Furthermore, two notions of historical development, civilisational and cultural, have been used to legitimise colonial violence, albeit in different ways. The turn to culture is informed by a desire to respond to civilisational history, which denies agency to those deemed 'backward'. In the case of Japan, the latter half of its colonial and imperial use of history was informed by the argument that making a new culture would introduce an alternative global order in East Asia. If this is indeed the case, the fault-lines for decolonising history must be redrawn. Specifically, it is not only the denial of agency that is problematic, but also the assertion of the self as the sovereign subject and maker of history.

\section{On the ambiguity of historicism}

As noted previously, the role of historicism in global politics can be observed in its imagining of particular places as historically behind those of the West. In his discussion of history-writing as part and parcel of colonialist knowledge, Ranajit Guha begins with a 
description, borrowed from Eric Wolf, of how European conquistadors identified the native inhabitants of the New World as a 'people without history' (2002: 8). Shifting to the discussion of South Asia, Guha writes, '[H]ere again the strategy was the same as the previous instance - that is, a joint operation of wars and words, modified only to the extent that the wars were to be British and the words German' (Guha 2002: 8). As Guha demonstrates, while the British waged wars to subjugate the Indians, the discourse was legitimised by German philosophers in their writings on world history. Specifically, Guha refers to Hegel's Philosophy of History, in which the latter transposes geographical differences into temporal differences by claiming that history begins in the stagnant Orient and culminates in the West (1988: 94). Such a linear account of historical development presumes a unitary direction of progress, which flattens diverse conditions and contexts into binary models of before-after, behind-ahead, and developing-developed. In this course of this abstraction, world history neglects the complexity, richness, and historicality of India, and instead defines it in terms of where it is positioned on this linear slope of historical development. Moreover, Guha argues, historicism is colonialist in that such depictions of India as 'backward' legitimised its expropriation, and the exploitation of Indian people, as part of the 'white men's burden' to 'bring up' and help 'advance' the Indians. Ultimately, Indians were to be molded in the image of their British colonial masters (Mehta 1999).

Likewise, Chakrabarty contends that the Western stagist view of history, which for him is equivalent to historicism, has served a particular function in the reordering of the global order in modernity:

Historicism enabled European domination of the world in the nineteenth century. Crudely, one might say that it was one important form that the ideology of progress or 'development' took from the nineteenth century on. Historicism is what made modernity or capitalism look not simply global but rather as something that became global over time, by originating in one place (Europe) and then spreading outside it. This 'first in Europe, then elsewhere' structure of global historical time was historicist [...] In the colonies, it legitimated the idea of civilization (2000: 7).

According to Chakrabarty, then, historicism served to legitimise and naturalise European domination. The schema of 'first in Europe, then elsewhere' pushes non-Europeans into the waiting room of history (Chakrabarty 2000: 8-9). With 'civilisation' deemed a universal good, it follows that those viewed as 'more civilised' than others ought to help those who are 'less civilised' to achieve this good. Such was the trick of historicism, which naturalised and legitimated European domination, and constructed 'civilisation' as a universal good to be aspired to.

Moreover, this machination of historicism extends well beyond the heyday of European colonialism. The language of deferral continues to exercise its power after decolonisation within modernisation theory and development studies, legitimating neocolonial relations between 'advanced' Western states and 'developing' states elsewhere (e.g. Inayatullah and Blaney 2004). Historicism, in this sense, continues to frame differences in terms 
of being 'ahead' or 'behind'. With Western powers having appointed themselves as the historical cutting edge, so to speak, 'modernisation' and 'developmental' prescriptions always begin with the same question: How can we make the rest look like the West? Historicism thus appears as necessarily complicit with colonialism and neocolonialism.

However, defining historicism in relation to the theory and practice of Western hegemony risks attributing an inordinate amount of coherence and stability to 'the West'. As Ann Laura Stoler has noted, this kind of analysis 'located "structure" with colonisers and the colonial state, and "human agency" with subalterns, in small gestures of refusal and silence among the colonized' (2009: 47). Indeed, for Guha, history-writing is equated with a hegemonic structure that silences and denies the voice and agency of the colonised (1997). This binary framework associates civilisation, history-writing, and a hegemonic structure with the coloniser, and human agency with the colonised. However, 'the West' as a theoretical category is by no means singular. ${ }^{1}$ While both Britain and Germany were colonial powers, to state that the war in India was fought by the British while the legitimising discourse came from Germany is to attribute undue coherence and singularity to Western colonial powers.

The fact that historicism did not embody a singular meaning is emphasised in the historian Maurice Mandelbaum's study of late $19^{\text {th }}$-century European political thought, from which Chakrabarty draws his definition of historicism:

Historicism is the belief that an adequate understanding of the nature of any phenomenon and the adequate assessment of its value are to be gained through considering it in terms of the place which it occupied and the role which it played within a process of development [ ... ] Essential to historicism is the contention that a meaningful interpretation or adequate evaluation of any historical event involves seeing it as part of a stream of history (1977: 42-3).

Chakrabarty takes up this definition, and connects the concept of historical development to progressive history and anachronism, which is associated with Enlightenment notions of civilisation; secularisation, and the attendant disenchantment of the world; as well as history: 'Crudely, one might say that it was one important form that the ideology of progress or "development" took from the nineteenth century on' (2000: 7-8). While acknowledging the tension between Ranke and Hegel, characterised as a tension between seeing historicism as individuality and as general law, Chakrabarty nonetheless associates historicism with the latter by connecting it to anachronism and the problem of transition. Phrased differently, by strongly associating historicism with anachronism, Chakrabarty externalises the other type of historicism - that which treats historical development as individuality.

Yet, Chakrabarty's consideration of Mandelbaum's study on historicism leaves out a vital caveat that, if taken seriously, warrants a modification of the charge against historicism. Specifically, while Mandelbaum acknowledges that 'development' and 'progress' both assume a directional property, the kind of history one might infer from these terms remains open. He writes, 
[...] there was no fundamental conflict between the views of those who conceived of history as subject to a law of Progress, and those who, on the analogy of the growth of living things, regarded development as an inherent tendency within cultures to unfold that which was implicit within them (Mandelbaum 1977: 44-5).

In essence, there was no conflict, strictly in terms of ordinary language usage, between cultural development and Progress.

The question that remains is to examine the stakes of scrutinising what may appear as a minor issue in Chakrabarty's reference to Mandelbaum. Although the stagist view of history continues to implicate and limit the ways in which the global hierarchy is constituted, the strong association made between Progressive history and historicism may prevent us from attending to the anti-Progressive view of history, which is also part of the history of historicism. This is not to fault Chakrabarty's definition of historicism, but to explore new questions by broadening the scope of historicism and its effects.

If historicism and Eurocentrism go hand in hand, then, as part of the project to reimagine global politics, we must ask how historicism can indeed be decolonised and provincialised. Nonetheless, interpretations of the role played by historicism in global politics continue to suffer from a schizophrenic ambiguity. In particular, this schizophrenic character of historicism points to the denial of the agency of those deemed 'backward' within a linear Progressive history on the one hand, and signifies the assertion and unfolding of one's agency and individuality against such a structure on the other. ${ }^{2}$ Despite differences in intent, both versions of historicism entail overlapping political consequences whereby domination is legitimised in the name of history. Historical development, however, did not always confine itself to civilisational history, or a Progressive rectilinear one.

In his studies of the history of historicism in Europe, Mandelbaum writes that the notion of historical development emerges from two disparate, yet interrelated, movements in the late $18^{\text {th }}$ century. The first is the extension of Enlightenment-era scientific thought about history, most notably in France and England. The second is the Romantic rebellion against Enlightenment history, which reimagined historical development in organicist and cultural terms, particularly in Germany. While these are tendencies at best, the radicalised form of this difference is reflected in the contemporary split over how historicism is to be defined in historiography more specifically and in international relations theory more broadly. On the one hand, historicism holds that there is a general law of historical development that could subsume that which is unique and particular. On the other, historicism acknowledges particularity, and defies the assumption that historical phenomena could be subsumed under any kind of general law.

Such a split is reflected in the literature about the relationship between historicism and international relations theory, which is rife with terminological disagreements (e.g. Hobson and Lawson 2008; Chakrabarty 2000; Vaughan-Williams 2005). For John Hobson and George Lawson, historicism 'is a mode of enquiry that recognises the specificity of events within their temporal and spatial contexts and rejects transhistorical categories' (2008: 10), whereas for Chakrabarty, historicism is what 'enabled European domination of 
the world in the nineteenth century' by naturalising and thereby generalising a cognitive structure that privileges the West as always being ahead of the rest (2000: 7; Mehta 1999; Spivak 1985). Between these two definitions, historicism stands for an emphasis on context and particularity on the one hand and a pretence to universal and general historical law on the other, which pays no attention to context, specificity, or difference.

In history, moreover, the definition of historicism remains no less elusive. In A Companion to the Philosophy of History and Historiography (2009), Robert D'Amico identifies three distinct definitions of historicism: (1) as historiographic concept: here the methods for studying historical phenomena and natural phenomena are considered distinct, therefore requiring disparate methods of interpretation; (2) as that which refers to historical laws and the assumption that laws of history exist, which allow for predictions and explanations of historical events; and (3) as an argument that the interpretation of history must be treated differently and independently from the aim of natural science, which is prediction and explanation (D'Amico 2009). In contention is the propriety of utilising the scientific method for the study of history, which, in Western modernity, became a realm of secular human affairs.

Taken together, the cacophony surrounding the term historicism arises out of disagreements over how, if, and whether scientific methods should be used to study human affairs. Furthermore, it scrutinises how social science is situated in relation to the methods employed in the natural sciences. The implicit question is whether what we regard as scientifically verifiable and thus 'objective' is actually so. If what is 'natural' and 'objective' is instead a social construct and product of unequal power relations, then the task of critical scholars of international relations - which is human affairs at large - becomes that of unveiling these underlying operations of power (Vaughan-Williams 2005). Still, the task of unveiling such relationships suffers from ambiguity about what the very term 'historicism' stands for.

Reflecting on these related yet contradictory versions of historicism, some Europeanists have responded to the call to provincialise Europe by drawing attention to the similarity between the work of German historicists (e.g. Herder) and Chakrabarty's critique of historicism (Dietze 2008: 75; Noyes 2014). As Noyes writes, Herder describes philosophers proposing general laws of history as 'mere asses', while valorising the diversity of language and culture, mourning the loss of local dialect and tradition, and calling 'Columbus an "assassin" for wreaking havoc on the New World' (Noyes 2014: 110). At the heart of Herder's critique of Enlightenment history-writing lies an impassioned opposition to generalisation and European claims to universality, which had buttressed its colonisation of and expansion into the New World (Muthu 2003).

Likewise, Dietze also notices the 'intentions shared by Herder and Chakrabarty' in that 'both recognize cultural differences, and criticize the idea that the histories of peoples all over the world can be adequately described and measured according to a set of European norms' (2008: 75). If historicism stands for pitting the particular against the purported universal, then Herder and Chakrabarty could be striving toward similar ends. Dietze then argues that Chakrabarty - just as much as Herder - is a 'thinker of radical Historismus trying to deconstruct the grand narratives of European Enlightenment rather 
than as a critic of the discipline of history' (2008: 75). In Dietze's definition of historicism, Chakrabarty is also an anti-imperial historicist.

In the late $18^{\text {th }}$ century, Germany had yet to fashion itself into a centralised nation-state and was, like the colonised, deemed 'less developed' in comparison to England and France, which were imagined as epitomising civilisation and positioned at its centre. Both Herder and Chakrabarty were writing 'on behalf of a country that is perceived as underdeveloped from the point of view of the theories they criticise' (Dietze 2008: 75). Put differently, Dietze and Noyes identify Chakrabarty's historicism as identical to Herder's politics of history, which focuses squarely on the dilemma of purported backwardness. In his reading of Herder, Noyes identifies a 'clear structural affinity between Herder's antimony of universal reason and the general project of postcolonial theory' (2014: 114), since what is at stake for postcolonial theory is the insistence that ubiquity does not equate to the universality of reason (Seth 2011).

If Chakrabarty's target is the tension between the universal and the particular, then Noyes's and Dietz's connection between his and Herder's historicism is not far off. As a response to Dietz, Chakrabarty acknowledges the resonance of the structural tension, but still wants Herder to be suspended in tension with Kant: 'I like some of the Herderian moves that Dietze makes. But I want my Herder constantly challenged by Kant, and vice versa' (2008: 95).

Chakrabarty's stance on the relation between the particular and universal is more nuanced than the representations by Noyes and Dietz. In particular, for Chakrabarty, the universal is both necessary and insufficient, as is the particular.

Still, for Chakrabarty to attribute Kant to universality and Herder to culturalism is a rather hasty reading, because Kant's many texts resonated differently, and had divergent aims. Both Herder and Kant, moreover, have been read in Germany as linking culture with the affirmation of political and historical agency. As Pheng Cheah demonstrates, in late $18^{\text {th }}$-century Germany, the Romantic preoccupation with Bildung and Kultur 'refer[s] to processes of human cultivation as well as organic forms' as a means of envisioning the endogenous assertion of one's autonomy (Cheah 2003: 38; Mensch 2013). Cultivation, moreover, is associated with organic forms because the term culture is a 'metaphorical extension of cultivation as agrarian activity' (Cheah 2003: 39). In the late $18^{\text {th }}$ century, as a reaction to industrialisation and the atomisation of social relations, culture became a vital link between the cultivation of inner spirituality and the phenomenal world. It is also around this time that the distinction between civilisation and culture was codified. Civilisation is 'mere civilization, which is concerned with external, sensuous, or material refinement', whereas culture - which is part of Bildung - is an imprint of humankind's ability to rework nature towards purposeful ends (Cheah 2003: 44).

This geopolitically specific conundrum of how to conceive of agency in history and nature in the Enlightenment period is reflected in Kant's divergent accounts of history and its relation to nature. In the Critique of Pure Reason and the Prolegomena, the world is conceived as a system of phenomena subject to necessary causal relations: man's actions are as predictable as the cycle of the moon (Kant 1981: xvi). While, in the Critique of Practical Reason, man is considered a biological being, part of a human species, man follows 
moral obligations arising from his own reason. Kant marks an important break from other Enlightenment thinkers in his account of how man's rational agency can develop. Whereas other Enlightenment thinkers saw rational maturity as a process of overcoming superstition, for Kant, rational agency also hinged on questions of autonomy. Moral autonomy requires that the rational law the agent is to follow emerges endogenously, and thus autonomously. If the law were to be given exogenously, this would negate both man's autonomy and his human dignity. This necessitates a reconfiguration of the world outside: nature and history are objects to be legislated according to man's internally derived reason: 'Autonomy requires that one interrupt the natural flow of inclinations, replacing the object's effect on the will with the motive of reason' (Hinchman 1996: 490-5).

There is a contrast between the image of history as being dictated by causal mechanis$\mathrm{ms}$ of nature on the one hand, and man as moral being who can legislate his own law and give law to nature on the other. The fact that man exists in both the sensible and rational worlds constitutes the abyss: how can man insist on the autonomy of his reason when he is also part of the sensible, natural world, which is dictated by causal mechanisms? Does man make history and exercise agency, or is he devoid of any volition of his own, unknowingly dictated by the laws of history? Can there be a sovereign subject of history?

Von Krockow characterises this abyss as a tension between structure and agency that has perpetually haunted the discourse on historicism. Here, the law of history is likened to a structure that dictates the agent's behaviour, and the view that the agent might exercise his agency becomes an argument for affirming man's volition and individuality (1999: 20, 25). The agent-structure dilemma is considered across different levels of analysis, and is not limited to the individual. Moreover, how can one know that man's exercise of agency can imprint itself on the phenomenal world? Kant's answer to this question is culture:

Man is indeed the only being on earth that has understanding and hence an ability to set himself purposes of his own choice, and in this respect he holds the title of lord of nature [ ... ] It is a formal and subjective condition, namely, man's aptitude in general for setting himself purposes, and for using nature (independently of [the element of] nature in man's determination of purposes) as a means [for achieving them] in conformity with the maxims of his free purposes generally (hence [in a way that leaves] that being free) is culture. Hence only culture can be the ultimate purpose that we have cause to attribute to nature with respect to the human species (1987 [1790]: 431-2).

Unlike animals, which are presumed to follow their natural instincts, man is capable of creating his own purpose. Man is the lord of nature because he uses nature as a means of achieving ends - 'he must have the understanding and the will to give both nature and himself reference to a purpose that can be independent of nature, self-sufficient, and a final purpose' (Kant 1987 [1790]: 432). It is cultural discipline that 'make[s] great headway against the tyranny of man's propensity to the senses, and so prepare him for a sovereignty in which reason alone is to dominate' (Kant 1987 [1790]: 432). Culture hints at the possi- 
bility of realising mankind's progress; it gives hope that there is a possibility of imprinting man's work on nature such that it will outlast the individual's short life span.

This leaves Kant with the problem of how to conceive of life in a way that is dynamic (allowing for the exercise of contingent freedom), yet also auto-causal (already containing a purposive direction). Given this complication, Kant turns to Johann Friedrich Blumenbach's theory of epigenesis, which considers organismic life as capable of self-formation and as rationally purposive (Cheah 2003: 54-5). As Mandelbaum observes, the dissociation of mankind's development from divine preformation - the idea that the form of an organic being is already present at the cellular level - allowed for imagining the development of bodies, both individual and social, as organismic. The notion of development as unfolding emerges from man's attempt to theorise his becoming free from external forces, whether divine or mechanical (Mandelbaum 1977: 57).

In this sense, the organismic metaphor of the political body represents an emancipatory hope. It serves as a fragile and tenuous link that sustains the image of man as an autonomous, moral being, and mankind as part of nature. The turn to the organismic metaphor is a response to the mechanistic vision of the world and of world politics, which threatens the possibility of spontaneity and creativity and of envisioning agency as inherent to man. Yet this organismic metaphor as a bridge over the abyss is tenuous, as Cheah notes, because it hinges on receiving a hint from nature about man's purposiveness while still attributing culture's impact on nature to man. Culture is now 'a self-reflexive activity that brings forth in a rational creature this ability to set ends at all' (Cheah 2003: 97). This shows how the later appeal of Romantics to nature and culture was underwritten by a desire to associate historicism with more agency-affirming ends.

According to Mandelbaum, by the end of the $18^{\text {th }}$ century there were two ways of comprehending history: (1) historical development as a process, which is history in the 'superficial, outer mode'; and (2) as a 'mode by means of which man can penetrate to the inner springs of power - sympathetic understanding of culture' (1977: 59). Therefore, different approaches to historicism are engendered from the interaction between Enlightenment progressive history and the Romantic rebellion. The second kind of historicism, or cultural historicism, is distinct from civilisational historicism in the sense that it revolts against the imposition of an external standard. Thus, whereas the first type of historicism is agency-denying, as Chakrabarty rightly points out, the second is agency-enabling. ${ }^{3}$

Only by acknowledging both versions of historicism can we identify the appeal of historicism in places where European imperialism provoked native intellectuals to reconfigure the meaning of history for themselves. As Kant's conundrum epitomises, the turn to culture as the site of realising man's freedom is motivated by the search for autonomous ways of relating to history. The differentiation between these two versions of historicism arises from the implicit contention over how to locate agency: thinking history alternatively can be constitutive in conceptualising political agency. 


\section{A different view of historical development: Kiyoshi Miki and the East Asia Cooperative Body}

It was not only in Germany but also in Japan that Kant's linkage of culture to the affirmation of agency in history was actively read into rethinking global politics. Kiyoshi Miki, for instance, takes up Kant's Third Critique to reflect on the significance of a discourse on Kultur in Japan. In his 1928 article 'Kagakuhihan no kadai' ('The Task of a Critique of Science'), Miki identifies this hidden thematic of Western political thought, which begins with the Greek notion of history as poetry; passes through the birth of individuality in Renaissance Italy, the rise of the natural sciences, and the secularisation of the Christian concept of time to Dilthey's existentialism; and finally oscillates between grounding history objectively and subjectively. The latter approach ultimately leaves the question of who the sovereign subject of history is unanswered (Miki 1975).

Before turning to Miki's texts, I will offer a brief historical context for Japan's vexed encounter with the Western concept of history-writing. With the Meiji Restoration of 1868, Japan pursued a path of Westernisation. The government's slogans were 'fukoku kyohei' ('rich nation, strong army'), and 'bunmei kaika' ('civilisation and opening'). The most influential writings on civilisational history to be translated and circulated at that time were Henry Thomas Buckle's History of Civilization in England (orig. 1857, trans. 1875) and Francois Guizot's General History of Civilization in Europe (orig. Histoire de la civilisation en Europe 1828, trans. 1877). These writings were avidly read by various figures in early Meiji Japan. According to Nagahara, the two historical schools of thought that became influential at the beginning of the Meiji period were that of Enlightenment history (bunmeishi), led by figures such as Yukichi Fukuzawa (1834-1901) and Ukichi Taguchi (18551905) on the one hand, and the 'national' school of textual analysis (koshogaku) led by Yasutsugu Shigeno (1824-1910) and Kunitake Kume (1839-1931) on the other (2003: 8-9). Civilisational history and science became the central currents in the early Meiji period.

Texts by Buckle and Guizot were popular among the Japanese reading public for their potential to reveal the secrets of Western power. The imposition of unequal treaties and the British defeat of Qing China weighed heavily on the minds of many, and histories accounting for the rise of the Western powers were reached to as a model for development. Buckle's claim of the existence of a law of progress and development in society resonated with readers in Japan. What was in demand was a 'how-to' book, not one on objectively studying a particular country's history.

Yukichi Fukuzawa offers us one example of engagement with civilisational history, bunmeishi, by theorising it as an endeavour to capture the positionality of the subject against the universal law of development. Fukuzawa's Outline of a Theory of Civilization (1875) begins with a promise to reveal the West's secret to attaining civilisation. Following Guizot and Buckle, Fukuzawa writes that an understanding of the different stages of civilisation is now 'accepted by people all over the globe' (2009: 17-8). In this three-tier civilisational schema, Japan is positioned as a semi-developed country, with Europe and the US as developed, and Africa and Australia as primitive (2009: 17). Fukuzawa, then follows 
this diagnosis of the present with a warning that if man remains content with the current stage of semi-development, the loss of autonomy may be inevitable.

How, then, are the three stages of development differentiated in Fukuzawa's outline? Here, Fukuzawa's employment of the stagist view of history echoes the progressive strain of historicism. In the primitive stage, men live in a precarious state where food and shelter are not reliably available. Here, 'man is still unable to be master of his own situation; he cowers before the forces of nature, and is dependent on the favours of others, or on the chance vagaries of nature' (2009: 18). The second stage consists of a more stable supply of basic necessities and institutions, which 'create an outward semblance of a state. The pursuit of book learning becomes more feasible, yet it is 'not yet civilization', for it lacks devotion to 'practical learning' (jitsugaku) and the 'courage to raise doubts'. Men in the semi-developed stage remain 'slaves of custom', as one can follow rules, but cannot create them. Man is 'adept at imitative craftsmanship', yet this craft remains at the level of mimesis. Man, in the civilised stage, where Europe and America stand, identifies the general structure that governs the universe, yet is unbound by the structure itself. Instead of slavish imitation, fully developed man demonstrates his capacity for the free play of thought. Learning is no longer imitative, but creative and inventive. Man is no longer a slave of custom; he actively plans the future, and commits to its realisation as a creator of the world (2009: 18-9). Fukuzawa specifically identifies inventiveness as a trait that differentiates Japan and China from Europe and America. China, in his imagining, is a country bound by old customs and habits. In Fukuzawa's eyes, the Opium War and its outcome made sense as a battle between the inventive British and the custom-bound Qing, which was punished for remaining content with the civilisation it had developed a long time previously.

Although Fukuzawa repeatedly draws on Buckle and Guizot, he makes no mention of climate, and instead attributes the development of civilisation to inventiveness and practical learning. What Fukuzawa seeks to promote is creative inventiveness. Furthermore, though designating Europe and America as the most civilised of countries, Fukuzawa qualifies this as a relative phase (2009: 20). China, for instance, is more civilised than Africa, and Europe is civilised as opposed to China. Yet, if someone were to look back at the present from the future, the present state of Europe would 'surely seem a pitifully primitive stage' (2009: 20). Here, Fukuzawa renders the notion of civilisational history as an open-ended process and, in doing so, sustains the possibility of and necessity for Japan to pursue practical learning and inventive craftsmanship. By regarding the developmental process as open-ended, Fukuzawa reconfigures civilisational history as a study identifying a universal pattern of social development while also offering the possibility of exercising control over this process by understanding the 'general structure' (2009: 18-9).

Equally notable for introducing civilisational history was Ukichi Taguchi, who wrote Nihon Kaika Shoshi (A Short History of Japanese Civilization) in 1877. Taguchi's history of civilisation is focused on material progress, and resembles Adam Smith's depiction of societal development from a nomadic society to a commercial, urban one. Similar to Fukuzawa, Taguchi is committed to finding the universal principles that lie behind civilisational history. Taguchi differentiates historical writings, which merely compile data chronologically, from those that identify the underlying causal relation between events. 
Like Buckle's premise for the study of English civilisational history, the aim of historical study for Taguchi is to reveal an underlying law that governs social phenomena.

For Fukuzawa and Taguchi, historical progress is identifiable through the application of universal law. While history is an 'open-ended process' for the former, each state's progressive histories are incomparable, at least not in any scientific way, for the latter. Both adopt the notion of universal law, yet neglect geographical determinism (e.g. the effect of climate on civilisational temper). Such were the brief engagements with the civilisational, stagist, and scientific views of history in early Meiji Japan.

Despite Fukuzawa's and Taguchi's efforts, the bunmeishi (civilisational history) school eventually lost its appeal because, regardless of domestic and legal reforms aimed at achieving the 'standards of civilization', it became increasingly evident that the issue of race could not be circumvented. In the 1886 Normanton Incident, a British captain was acquitted on charges of letting all 37 non-Western members of his crew (Japanese, Chinese and Indian) drown when his ship sank. The captain rescued every British and German crew member, which incited outrage at the unequal treatments (Tanaka 1990). The incident demonstrated that regardless of one's strivings to be 'civilised,' one's civilisational status was ultimately determined by one's skin colour.

In the late $19^{\text {th }}$ century, this conflation of historical underdevelopment or stagnation with particular geographical regions became fixed in Eurocentric civilisational historical narratives (McCarthy 2009). This left thinkers in Asia with a complex predicament: to affirm the idea of historical development was to deny one's agency, since Europe depicted Asia as a calcified, backward site without historical movement. However, in adopting a stagist approach to history, this denial seemed unavoidable. The problem of how to think about historical development in Asia has therefore revolved around the question of how to conceive of political agency. It is here that we begin to see the Romantic moment.

In short, what we see in the first half of the Meiji period is an engagement with French and British civilisational histories and their approach to history as a science. In addition, we can observe the eventual realisation that the study of history, for Japan, requires a different approach -one that is opposed to civilisational history altogether. To be sure, civilisational history, which conceives of Asia as backward, does not die out in the 1890s. As Stefan Tanaka shows, this Western idea of Asia as backwards is replicated in the establishment of Oriental Studies programmes by Japanese universities (1995). By claiming that it is more civilised than other Asian states, Japan reproduces the civilising mission of the West in Korea, ultimately leading to Japan's colonisation of Korea in 1910 (Dudden 2006).

Yet these accounts of a Westernising Japan do not capture the alternative approaches to history that emerged after the 1890s as a reaction to the limits of civilisational history. As the historian Kevin Doak writes, the overarching concern of intellectuals in the first half of Meiji was about 'civilization, universal development, [and] participation in the international system'; however, these aspirations were met with setbacks internationally (2007: 170). By the 1890s, there was broad consensus that civilisational history was Western history. It was against this backdrop that a different notion of Asia emphasising cultural difference gradually became resurgent. From then on, 'a romantic, historicist nationalism that asserted the particularity of the Japanese ethnic nation' became prominent 
(Doak 2007: 184). The cultural turn, which became dominant from the 1890s onwards, rendered Asia not as a static and backward empire, but as a site of resistance.

In 1938, the philosopher Kiyoshi Miki wrote that political theory capable of uniting the East lay in the defeat of world history as the history of white people; that is, Eurocentrism (2007: 43). The issue identified by Miki is the question of how to pluralise the ways in which we consider historical development. By then, Miki headed the cultural division of the Showa Research Association (SRA), an advisory committee which served as a think-tank that advised Prime Minister Fumimaro Konoe on his Asia policy. Miki's treatise on history was written amid the convergence of three transnational intellectual movements: (1) the Pan-Asianist movement that sought to redefine what 'Asia' symbolised in history and worked in tandem with; (2) the rise of a view of Kultur as an antidote to civilisation that, in combination, enabled (3) 'Asia' to be reconfigured as a spiritual giant which was no longer perpetually 'backward', as defined by the West. The fusion of these trends is reflected in the treatise on international politics, Principles of Thought for a New Japan, published by the SRA under Miki's leadership. This treatise, which was issued in two parts, is considered to be the most thorough, systematic response to Eurocentrism in history to be written at the time of World War II (Hiromatsu 2006: 126-7).

As Tetsuya Sakai writes, Japanese theorists in the period after World War I - that is, in the interwar period - shared a sense of a worldwide crisis in the international order (2007: 33). In light of this crisis, both the members of the SRA and those of the later conference on 'Overcoming Modernity', identified the Marco Polo Bridge Incident - the first clash between the Japanese and Chinese military, which started the Sino-Japanese war - as evidence that world history was witnessing a simultaneous decline of Eurocentric history, along with the emergence of a new kind of history in the East. ${ }^{4}$

Miki's work on historicism was strictly theoretical in the beginning. One of his first writings on the possibility of critique and historicism was based on a reading of Kantian idealism as a gateway to the later German Romantic movements. In addition, Miki discussed the import of culture as a realm in which mankind's autonomy could be manifested. Under the increasing suppression of free speech and thought in the 1930s, the only way in which he could express his thinking was to publish in journals. In this political context, his short article on the meaning of the Marco Polo Bridge Incident attracted the attention of members of the SRA. Miki was subsequently invited to address them, and was later appointed as the head of the SRA's cultural division. The Principles for a New Japan (Shin Nihon no Genri) later became a blueprint for Prime Minister Konoe's declaration of the New World Order in Asia in the 1940s.

Principles $I$ begins by identifying the historical significance of the war, and argues for the impossibility of finding a solution to the Sino-Japanese war without pursuing domestic reform. Spatially, it argues, the significance of the war lies in the unification of East Asia, which accords with a world movement toward the formation of regional blocs - itself a movement toward the spatio-temporal unification of world history (Miki 2007: 177-8). To facilitate this world-historical movement, Principles I argues that Japan ought to 'help' China achieve modernisation, which requires expelling Western imperialist influ- 
ence from China. At the same time, if China is to join the united East, it must avoid both digressing into its feudal past and being captured by modern capitalism.

Principles I distinguishes between East and West. The East is based on the culture of the kingly way of rule (wangdao), the fusing of man and nature, the thought of heaven (tian), and the communitarian way of thought. By contrast, the West is characterised by individualism, humanism, rationalism, liberalism, and the principle of atomistic self-interest (Miki 2007: 179-180). Since the East, unlike the West, does not share a common preexisting culture, the creation of a new culture that would overcome the limits of Western abstraction while avoiding a return to the East's own feudalistic ways must be pursued. According to Miki, 'given that the crisis of the world is caused by the limitation of westernled capitalistic order, the new culture must also seek to overcome the limit of both' (2007: 181).

Subtly echoing Fukuzawa's call for creative inventiveness, given how in Principles I both the pre-existing Western concepts and return to tradition were disavowed, the question of how to theorise praxis turns into a matter of poietic creativity. Principles II begins by identifying the Sino-Japanese War as a Holy War, executed in the name of building a new order in East Asia (Miki 2007: 194). The basis of this new principle of thought is co-operativism, a practice whose basis lies in the act of making. This practice as poiesis pertains to the unification of the objective law of nature with the subjective human will. The theory of this practice is one of historical production and historical creativity: 'we are made by history and, conversely, makers of history' (Miki 2007: 202).

The historical meaning of the war hinges on the act of making, that is, of creating a new order. This act of making is aimed at overcoming the debates about whether history determines outcome, or whether the development of history is itself determined by an agent. Principles II addresses this question through its philosophy of form, where the notion of the form and the maker of the form is likened to artistic production. Principles II denies that artistic production is merely mimetic. The artist may be copying an object before his eyes, yet the copying is only possible with the active engagement of the copier. Because this engagement is active and selective, what is being copied is not the same as the copy. Principles II, The New Principle of East Asia, is about this formative production.

Principles II was a systematic clarification of the 1938 New East Asian Order proclaimed by Prime Minister Konoe a year after the Marco Polo Bridge Incident. It redefined the war aim as the making of a new culture. This not only legitimised theorists in the metropole, but also bolstered the efforts of soldiers on the ground in China. Imperial soldiers thus became 'cultural soldiers', with those in the occupied territories now considering their efforts as part of forging a new East Asian culture, form, and order (Inoue 2007: 68). Therefore, the war was about the cultural transformation of the Japanese domestic political order as well as that of Greater East Asia.

Because Principles I cautioned against mere expansion, or the imposition of Japanism, the clarification of the war aim resonated with those who remained critical of Japanese imperialism. In this sense, Principles I and II were more potent in endowing legitimacy to the war than the ideology of Japanism, which many intellectuals rejected for its ethnocentrism. The making of new culture sought to envision Sino-Japanese relations as the co- 
operative making of a new culture. Given the underlying utopic idealism tucked beneath the text, the plan to reform the existing, corrupt order attracted a diversity of supporters, including theorists, militarists, farmers, factory workers, and others seeking reform in Japan. Linking total war with a new kind of utopic regional order attracted support from across all strata of society. Among others, it led the socialist party to become a nationalist party.

Having provided a blueprint for legitimising the war as a means to reform both the Japanese and Asian political orders, the SRA was disbanded and, in 1940, absorbed into the Imperial Rule Assistance Association. The historian Eri Hotta argues that the significance of Miki's work lies in the extent to which he legitimised Japan's war, and in doing so prolonged the war. The efficacy of this newly defined war aim made it difficult for Japanese leaders to back out of the war, short of winning this unwinnable war of 'liberation' (Hotta 2007: 174-6). In the 1940s, the war to realise a new kind of order was reified by others following Miki who were not involved in the SRA. The Kyoto School of philosophers Masataka Kosaka, Iwao Koyama, and Masataka Suzuki - were conservative scholars who later participated in the conferences 'Overcoming Modernity' and 'Japan and its World Historical Standpoint.' The former subsequently identified the objective of the war as the making of a new world order with the latent challenge to the Eurocentric world order becoming more obvious once the war had been expanded to encompass Western powers.

Despite the caveat Miki added in Principles I, that Japan should not merely reproduce Western hegemony, the war ultimately became the one establishing Japanese dominance in the region. This replication of hegemonic power relations suggests that we need to further examine the problem of responding to the Western denial of Asian agency with the claim that to right such a wrong, we must render the formerly oppressed as the subject of history, and begin anew. Why are responses to the Western denial of historical agency susceptible to appropriation for imperialist ends?

In the attempt to critique Eurocentric norms through poiesis, as a means to practically create a different set of norms, Asia was likened to a malleable substance to be shaped by Japan, as both subject and maker of history. Because the Principle rejected any return to the past, the turn to culture entailed the making of new culture. Making, however, requires a maker: a subject of history. Although Miki continuously warned that Japan should not merely replace the Western powers in Asia, he nonetheless identified a special leading role for Japan as the initiator of this new culture. The appropriation of this call for a new order into legitimising Japanese imperialism was facilitated by a theoretical ambiguity of 'who' was to be the subject of history. Instead, this question was answered by practical political concerns. In the name of political realism, those who asserted that Japan should be this agent of history argued this to be so because it was one of the few countries that had escaped colonisation by the West.

By advocating a break from pre-existing Eurocentric thought as well as 'traditions' in Asia, Miki's Principles inadvertently lent its support to the idea that a new world order must be produced endogenously. In so doing, it enacted a blindness to plurality, as the exercise of historical agency became one of a singular sovereign subject projecting his/ her vision of the world order onto the world. Within such a process, there is little space 
for voices from Asia. It is in this sense, the historian Shinichi Yamamuro points out, that the discourse on new culture and imperial policy was more potent in legitimating colonial rule when culture did not refer to tradition, but to a making of something new (2004: 8081 ). A return to tradition would mean working with what is given to us. The making of new culture, in contrast, opens itself to a precarious claim: that anything is possible, and no reference to an actual Asia is necessary.

\section{Conclusion: on the politics of history}

What is one to make of this fact of collaboration and total mobilisation, as well as the potency of Miki's reformulation of historicism? As outlined above, the predicament is how resistance against Eurocentrism took the form of a cultural reconfiguration of historical significance, and how the cultural production of a new order came to legitimise and reproduce the kind of imperial violence that Miki originally sought to criticise. Civilisational history was problematic, as it naturalised Eurocentrism, yet the Japanese response crafted in the 1930s and 1940s continued to conceive of Asia as a theoretical problem, whose solution lay in the construction and projection of the New Order at the expense of Asian voices and dissent.

Indeed, the Principles lack any account of the facts on the ground, or any voices or critiques from Asia. This absence speaks to how the theorisation of a new Asia remained a theoretical exercise, having little to do with politics on the ground. The politicisation of culture in the name of resistance from the Chinese and Korean perspective was merely a new form of domination. While framed differently, the shift from the 'civilising mission' discourse to that of cultural governance remained a colonialist one. The concept of culture, which was supposed to offer a site of resistance against a civilisational discourse, legitimised violence in the name of incubating a new culture.

Two contradictory tendencies are embodied in historicism. The first is the problematic of how progressive linear history excludes those who are deemed to be 'backward'; the second is the dilemma of how challenges to purported universalism can slip into another oppressive discourse on historicism. While this is not to say that such a pattern will inevitably be replicated, the Japanese wartime discourse on culture and historical significance merits attention. Can responses to the denial of historical agency be theorised in a different way? Can we seek emancipation without equating this to a unilateral assertion of agency that blinds one to plurality? The dilemma, which binds our formally decolonised world is therefore whether we can think beyond the two types of historicism(s) - one that denies agency to the 'belated', and another that asserts agency in the name of history. What may come after historicism(s)?

Here I return to what is an arguably caricatured reading of Chakrabarty's conception of historicism, caricatured because he does not make a strongly structural reading of civilisation (and in fact seems to use the term civilisation and culture as interchangeable matters), although he repeatedly problematises the effect of the stagist view of history which for him stands for historicism - and how anachronism serves to close off our ability to acknowledge our different ways of being-in-the-world. How, then, does one contend 
with the stagist view of history? For Chakrabarty, this hinges on finding different ways of relating to past traditions, or what one might call culture, and acknowledging its contemporaneity: to disturb the relation between futurity and politics. Still, the resemblance of this stance to Miki's historicism, which is also critical of Eurocentrism, raises new questions. Is there a risk of closely identifying historicism with anachronism?

To be sure, Chakrabarty might as well characterise Miki’s historicism as decisionism, as it is bound by the desire to imagine alternative futures. In his final chapter, Chakrabarty draws a distinction between historicism/anachronism and decisionism, 'the revolutionary-modernist position in which the reformer seeks to bring (a particular) history to nullity in order to build up society from scratch', both bound to a 'desirable future'; and the ways of being that are not bound by 'the future that 'will be" (2000: 250). For the second way of being-in-the-world, Chakrabarty brings in the example of an Indian scientist who has no qualms about being a mathematician and an astrologer simultaneously (2000: 247). Nonetheless, does the distinction Chakrabarty draws between History 1 (of the analytical Marxist type) and History 2 (the hermeneutic affective writing of history for which he posits Heidegger as its representative) hold if we were to acknowledge the decisionist impulse - the assertion of agency unbound by history - evident in Kant, Heidegger and Miki? Chakrabarty safeguards this dichotomy by drawing out the distinction surrounding the relation between politics and the future. Yet this leaves one asking whether this could amount to conceding politics to history.

\section{Notes}

1 To be sure, Chakrabarty also underscores that the West and Europe are symbolic notions figures that differ from the actual geographical West and Europe. Nonetheless, he does not acknowledge how diverse regions within Europe engaged with historical differences in different ways.

2 Chakrabarty engages the tension between the general and the particular as that between the History 1 of Marx and the analytical tradition, and the History 2 of Heidegger and the hermeneutic tradition. This makes the engagement with Miki all the more relevant since he, too, grappled with history in terms of these two conceptions, which makes the incorporation of questions of culture in historicism important.

3 The distinction drawn here between civilisation and culture is tentative, for the sake of differentiating the rationale given by Miki.

4 The Kyoto school philosophers were Hegelian. However, in this article I focus on the problem of culture and sovereignty as posed by Kant and interpreted by Miki.

5 Miki himself was also a disciple of Nishida and Tanabe, but is differentiated along with Jun Tosaka for his Marxist sympathies. The other disciples are grouped as Kyoto School conservatives.

\section{References}

Chakrabarty, Dipesh. 2000. Provincializing Europe: Postcolonial Thought and Historical Difference. Princeton: Princeton University Press. 2008. 'In Defense of 'Provincializing Europe': A Response to Carola Dietze'. History and Theory 47 (1): 85-96. 
Cheah, Pheng. 2003. Spectral Nationality: Passages of Freedom from Kant to Postcolonial Literatures of Liberation. New York: Columbia University Press.

D’Amico, Robert. 2009. 'Historicism' In Aviezer Tucker (ed), A Companion to the Philosophy of History and Historiography. Singapore: Wiley-Blackwell.

Dietze, Carola. 2008. 'Toward a History on Equal Terms: A Discussion of Provincializing Europe, History and Theory 47 (1): 69-84.

Doak, Kevin. 2007. A History of Nationalism in Modern Japan. The Netherlands: Brill.

Dudden, Alexis. 2006. Japan's Colonization of Korea: Discourse and Power. Hawai'i: University of Hawai'i Press.

Fukuzawa, Yukichi. 2009. An Outline of a Theory of Civilization. New York: Columbia University Press.

2013. An Encouragement of Learning. New York: Columbia University Press.

Guha, Ranajit. 1997. Dominance without Hegemony: History and Power in Colonial India. Cambridge: Harvard University Press.

2002. History at the Limit of World-History. New York: Columbia University Press.

Hegel, Georg. 1988. Introduction to the Philosophy of History. Indiana: Hackett Publishing.

Hinchman, Lewis. 1996. 'Autonomy, Individuality, and Self-Determination'. In James Schmidt (eds), What is Enlightenment? Eighteenth-Century Answers and Twentieth-Century Questions. Berkeley, Los Angeles, London: University of California Press.

Hiromatsu, Wataru. 2006. Kindai no Chokokuron: Showa Shisoshi he no ichi shikaku [Overcoming Modernity: A Perspective on Political Thought of Showa Period]. Tokyo: Kodansha Gakujsutsu Bunko.

Hobson, John and George Lawson. 2008. 'What is History in International Relations?' Millenium 37(2): 415-435.

Hotta, Eri. 2007. Pan-Asianism and Japan's War 1931-1945. New York: Palgrave Macmillan.

Ienaga, Saburo. 2003. Ichi Rekishigakusha no Ayumi [A Historian's Path]. Tokyo: Iwanami Gendai Bunko.

Inayatullah, Naeem and David Blaney. 2004. International Relations and the Problem of Difference. New York: Routledge.

Inoue, Toshikazu. 2007. Nicchu Sensoka no Nihon [Japan under Sino-Japanese War]. Tokyo: Kodansha Sensho Metier.

Kant, Immanuel. 1987 [1790]. Critique of Teleological Judgment. Indianapolis, Indiana: Hackett Publishing.

Krockow, Christian. 1999. Die Entscheidung [Decisionism: Junger, Schmitt, Heidegger]. Tokyo: Kashiwa Shobo.

Mandelbaum, Maurice. 1977. History, Man and Reason: A Study in Nineteenth-Century Thought. Baltimore: Johns Hopkins University Press.

McCarthy, Thomas. 2009. Race, Empire, and the Idea of Human Development. Melbourne: Cambridge University Press.

Mehta, Uday Singh. 1999. Liberalism and Empire: A Study in Nineteenth-Century British Liberal Thought. Chicago: University of Chicago Press. 
Mensch, Jennifer. 2013. Kant's Organicism: Epigenesis and the Development of Critical Philosophy. Chicago and London: University of Chicago Press.

Miki, Kiyoshi. 1975. 'Kagakuhihan no Kadai [On the Task of Critique of Science]'. In Gendai Nihon Shiso Taikei [Contemporary Japanese Political Thought] 33. Tokyo: Chikuma Shobo.

2007. 'Toa Shiso no Konkyo [Ground of East Asian Thought]'. In Hiroshi Uchida (ed),

Miki Kiyoshi Toa Kyodotai Ronshu [Essay Collections of Kiyoshi Miki's Theory of East Asian Cooperative Body]. Tokyo: Kobushi Shobo.

Muthu, Sankar. 2003. Enlightenment against Empire. Princeton: Princeton University Press.

Nagahara, Keiji. 2003. Seiki Nihon no Rekishigaku [The Japanese Discipline of History in Twentieth Century]. Tokyo: Yoshikawa Kobunkan.

Noyes, John. 2014. 'Herder, Postcolonial Theory and the Antinomy of Universal Reason', The Cambridge Journal of Postcolonial Literary Inquiry 1 (1): 107-122.

Sakai, Tetsuya. 2007. Kindai Nihon no kokusai chitsujoron [The Political Discourse of International Order in Modern Japan]. Tokyo: Iwanami Shoten.

Seth, Sanjay. 2011. 'Postcolonial Theory and the Critique of International Relations,' Millennium 40 (1): 167-83.

Spivak, Gayatri. 1985. 'The Rani of Sirmur: An Essay in Reading the Archives', History and Theory 24 (3): 247-272.

Stoler, Ann Laura. 2009. Along the Archival Grain: Epistemic Anxieties and Colonial Common Sense. Princeton: Princeton University Press.

Taguchi, Teiken. 1977. Taguchi Teiken Shu [Collection of Writings by Teiken Taguchi]. Tokyo: Chikuma Shobo.

Tanaka, Masahiro. 1990. 'Normanton Incident'. In The Comprehensive National History Reference, Vol. 11. Tokyo: Yoshikawa Kobunkan.

Tanaka, Stefan. 1995. Japan's Orient: Rendering Pasts into History. Berkeley and Los Angeles, California: University of California Press.

Vaughan-Williams, Nick. 2005. 'International Relations and the 'Problem of History", Millenium 34(1): 115-136.

Yamamuro, Shinichi. 2004. Shiso Kadai to Shiteno Ajia [Asia as a Theoretical Problem]. Tokyo: Iwanami Shoten.

\section{Acknowledgements}

I would like to thank the anonymous reviewers for their generous and insightful comments, and Casey McNeill and Mariam Banahi for their helpful suggestions.

\section{About the author}

Hitomi Koyama is a postdoctoral research fellow of non-western international relations theory at the Institute for Social Justice of the Australian Catholic University. She holds a $\mathrm{PhD}$ in international relations theory from Johns Hopkins University, Baltimore, where she completed a dissertation on international politics of history with a regional focus on 
East Asia. Her work spans comparative political theory, critical international relations theory, (post)colonialism, and the history of imperialism. At the moment she is interested in how morality is bound to a progressive image of time, and how this implicates the very act of writing about and remembering the past.

Received on 10 January 2016, and approved for publication on 13 July 2016.

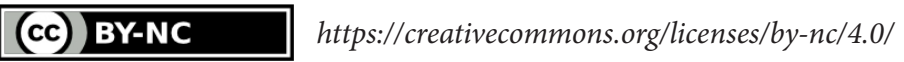

